\title{
Chemical Inducers for Resistance Induction against Powdery Mildew of Cucumber under Greenhouse Conditions
}

\author{
A. HAMZA ${ }^{1}$, A. MOHAMED ${ }^{2}$ and A. DERBALAH ${ }^{1 *}$ \\ ${ }^{1}$ Faculty of Agriculture, Pesticides Chemistry and Toxicology Department, \\ Kafr-El-Sheikh University, 33516 Kafr-El-Sheikh, Egypt \\ ${ }^{2}$ Agricultural Research Centre, Plant Pathology Research Institute, Giza, Egypt
}

(Received: 16 November 2016; accepted: 8 December 2016)

\begin{abstract}
This study was completed to assess the efficacy of certain chemical inducers (potassium dihydrogen phosphate, potassium monohydrogen phosphate, oxalic acid, salicylic acid, sodium salicylate, ferrous sulfate and magnesium sulfate) compare to flusilazole fungicide against Sphaerotheca fuliginea, the causative fungus of powdery mildew of cucumber under greenhouse conditions. The impact of these elicitors on some biochemical and growth characters of cucumber was also examined. The data demonstrated that the flusilazole was the best treatment against powdery mildew followed by salicylic acid, potassium dihydrogen phosphate, magnesium sulfate, ferrous sulfate, oxalic acid and potassium monohydrogen phosphate, respectively. Marked raise in the measured biochemical parameters (chlorophyll content, peroxidase and polyphenoloxidase) of treated cucumber compare to untreated control. Growth and yield characters (plant height, number of fruits/plant and yield/plant) of cucumber were remarkably increased in cucumber treated with examined elicitors compare to untreated control. The examined chemical inducers could be counted as stand by for control powdery mildew of cucumber.
\end{abstract}

Keywords: Powdery mildew, cucumber, chemical inducers, fungicide, control.

Powdery mildew (Sphaerotheca fuliginea Pollacci) is a standout amongst the most dangerous fungal pathogens faced in cucumber plants grown under greenhouse. Occasional use of fungicides to control powdery mildew considered a source of major concern worldwide that the utilization of fungicide induces potential harmful effects on the human health and domestic animals and leads to environmental pollution. Moreover, the heavily and longtime utilization of chemical fungicides led to resistance evolution in this fungus (Pasche et al., 2004). The Fungicide Resistance Action Committee (FRAC) has relegated a moderate danger of resistance evolution to several fungicide active ingredients presently listed for use against cucurbit powdery mildew (Brent and Holloman, 2007; Fungicide Resistance Action Committee, 2011). P. xanthii evolve resistance (insensitivity) to fungicides more promptly than other fungal pathogens do (Russell, 2004). This is especially correct in greenhouses, since once the fungus presented; the population itself is

\footnotetext{
* Corresponding author; e-mail: aliderbalah@yahoo.com
} 
frequently exposed to fungicides with consecutive implementation (Brent and Holloman, 2007; McGrath, 2001).

Thus, a more balanced, low cost and environmentally safe trend must be used by growers. So as to overcome such severe control methods, specialists, researchers from everywhere throughout the world gave a major concern to find out new methods that environmentally safe, harmless to humans and animals and are quickly biodegradable.

Systemic acquired resistance (SAR) and induced systemic resistance (ISR) are two kinds of resistance; in both SAR and ISR, plant became ready to defense before infection that results in resistance (or tolerance) against the pathogen (Ragab et al., 2009). Many efforts have been taken over the last two decades in comprehension the physiological and biochemical basis of SAR and ISR. A lot of this information was because of the recognition of numerous chemical and biological inducers; some of which are traditionally accessible for use in routine farming (Vallad and Goodman, 2004).

Since economic thresholds have not been set up for most plant pathogens, an integrated pest management (IPM) takes a little various trend in controlling plant disease. Several studies on powdery mildew control on various crops have been used mineral salts as foliar application agents. In this manner, potassium bicarbonate applications found to be efficient in reducing powdery mildew severity on Euonymus japonica and pumpkin (Ziv and Zitter, 1992; Ziv and Hagiladi, 1993). In pot trial, under artificial infestation with the pathogenic fungus, the use of sodium bicarbonate or calcium chloride markedly decreased the incidence and severity of early blight pathogen (El-Mougy and Abdel-Kader, 2009). Also, potassium salts $\left(\mathrm{K}_{2} \mathrm{HPO}_{4}\right.$ or $\left.\mathrm{KNO}_{3}\right)$ as chemical agents for induction of plant resistance showed incredible consideration in numerous of these reports (Stromberge and Brishammar, 1991; Marin et al., 2002).

These reports urged us to assess the potential use and the efficacy of foliar application of mineral salts and inorganic acids as resistance inducers on vegetables to give satisfactory control level of powdery and downy mildews under greenhouse conditions.

Thus, the present study was done to control Sphaerotheca fuliginea, the causative organism of powdery mildew pathogen of cucumber by utilizing certain synthetic inducers (potassium dihydrogen phosphate, potassium monohydrogen phosphate, oxalic corrosive, salicylic corrosive, sodium salcylate, ferrous sulfate and magnesium sulfate) alongside the recommended fungicide flusilazole under greenhouse conditions in two growing seasons, to estimate the induction effect of various defense enzymes in treated cucumber plants in light of the inducers application and to assess the impact of these inducers on some growth and yield characters of cucumber.

\section{Materials and Methods}

\section{Chemicals}

Flusilazole fungicide with trade Punch $40 \%$ EC produced by DuPont International Operations S.a.r.1. 2, chemin du PavillonCH-1218 Le Grand-Saconnex / GE; Switzerland was used in this study. Potassium dihydrogen phosphate, potassium monohydrogen phos- 
phate, oxalic acid, salicylic acid, sodium salycilate, ferrous sulfate and magnesium sulfate with high purity were obtained from El-Gomhoira Company for Glasses and Chemicals, Tanta, Egypt.

\section{Greenhouse experiment}

The experiment was performed at Sakha Research Station in controlled greenhouse. Fifteen days old cucumber (Celebrity cultivar) seedlings were transplanted using paired row in every edge. The plot length was $3.5 \mathrm{~m}$ with a width of $1.5 \mathrm{~m}$ and every plot contained 14 cucumber plants. Randomized complete block design was used in this experiment with four replicates for each treatment with conventional culture practices. The mean temperatures were $22 \pm 2{ }^{\circ} \mathrm{C}$ and $18 \pm 2{ }^{\circ} \mathrm{C}$ within the day and night, respectively and the day light was $12 \mathrm{~h}$ with humidity of $65-72 \%$. Chemical elicitors and flusilazole were applied as protective spray before cucumber plants naturally infected by powdery mildew under greenhouse conditions after 30 days of planting (10 days after transplanting). Chemical inducers applied at rate of $20 \mathrm{mM}$ (El-Mougy et al., 2013) while the fungicide at rate of $6 \mathrm{ml} / 1001$ water. The used concentration of chemical inducers was selected after evaluation of several concentrations of it $(5,10,20$ and $40 \mathrm{mM})$ against infected cucumber plants. The concentration of $20 \mathrm{mM}$ of chemical inducers was the best one that highly reduced the disease severity without phytotoxicity on cucumber plants). However, the concentrations lower than $20 \mathrm{mM}$ showed low reduction in disease severity and the concentration higher than $20 \mathrm{mM}$ induced phytotoxicity on cucumber plants (data not published). All treatments were applied three times with intervals of 15 days between each spray and severity was assessed after the last spray.

\section{Disease assessment}

To assess disease severity, five leaves from each plant with five plants in every plot (i.e. 25 leaves/treatment) were examined. Fully expanded leaves from the middle and upper thirds of a plant were assessed and data were averaged. The severity of powdery mildew infection was estimated following the scale from 0 to 5 that used by Townsend and Heuberger (1943). Infected cucumber leaves were ordered in five categories, where: $0=$ no mildew, $1=1-25,2=26-50,3=51-75,4=76-100$ and $5=$ more than 100 colonies/leaf (Mahdy et al., 2006). Powdery mildew severity was calculated using the following equation:

$$
\mathrm{P}=\Sigma(\mathrm{n} \times \mathrm{v}) / \mathrm{SN} \times 100
$$

Whereas, $\mathrm{P}=$ expresses the percentage of disease severity $(\%), \mathrm{n}=$ expresses infected leaves number in each category, $v=$ expresses each category numerical value, $\mathrm{S}=$ expresses the highest ratting value and $\mathrm{N}=$ expresses total number of the infected leaves.

The efficiency of the tested treatments expressed as reduction percentage in powdery mildew severity was calculated by following equation:

Reduction $(\%)=$ disease severity in control - disease severity in treatment / disease severity in control $\times 100$ 


\section{Biochemical analysis}

Determination of chlorophyll

Leaf samples of $0.2 \mathrm{~g}$ from each treatment were cut into small parts and putted in a glass vial containing $2 \mathrm{~mL}$ of $\mathrm{N}, \mathrm{N}$-dimethylformamide (DMF) and were covered with aluminum foil. The vials were then incubated at $4{ }^{\circ} \mathrm{C}$ for $48 \mathrm{~h}$ (Moran and Porath, 1980). The absorbance of chlorophylls $\mathrm{a}$ and $\mathrm{b}$ were measured at wave lengths of $663 \mathrm{~nm}$ and $645 \mathrm{~nm}$, respectively, with a UV-visible spectrophotometer (Genesys 10UV, Thermo Fisher Scientific, USA) using DMF as a blank. Chlorophylls a and b were calculated using the following equation as described by Arnon (1949).

Ch $. \mathrm{a}=0.0127(\mathrm{~A} 663)-0.00269(\mathrm{~A} 645)$

Ch $. b=0.0229(\mathrm{~A} 663)-0.0468(\mathrm{~A} 645)$

\section{Sample preparation and extraction for determination of the enzymes activities}

For each treatment, $5 \mathrm{~g}$ of cucumber leaves were collected (five leaves from each plant and three plants from each replicate of each treatment) after the last spray and stored at $-80{ }^{\circ} \mathrm{C}$ until used. Enzymes extraction procedures were conducted at $4{ }^{\circ} \mathrm{C}$. The samples were ground with $0.1 \mathrm{M}$ sodium phosphate buffer at $\mathrm{pH}$ of 7.1 ( $2 \mathrm{ml}$ buffer/g tissue) in a mortar. These mashed tissues were squeezed using four layers of cheese cloth and the obtained filtrates were centrifuged at $3000 \mathrm{G}$ forces for $20 \mathrm{~min}$ at $6{ }^{\circ} \mathrm{C}$. The supernatant fluid was used to determine defense enzymes activity.

\section{Polyphenoloxidase assay}

The method described by Galeazzi et al. (1981) was used to assess polyphenoloxidase (PPO) activity in cucumber leaves. In this process, $100 \mu \mathrm{l}$ of crude plant extract was combined with $2 \mathrm{~mL}$ of $0.05 \mathrm{M}$ phosphate buffer $(\mathrm{pH} 7.0$ ) and $0.5 \mathrm{ml}$ of $0.5 \mathrm{M}$ catechol and then incubated at $24^{\circ} \mathrm{C}$ for $2 \mathrm{~min}$. After that the absorbance of the mixture at $398 \mathrm{~nm}$ was measured using spectrophotometer. The PPO activity, U398, was calculated using the following equation:

$$
\mathrm{U} 398=0.01 \Delta \mathrm{OD} 398
$$

where U398 is the unit of enzyme at 398 wavelength, and $\Delta \mathrm{OD}$ is the change of absorbance per mg of protein per min.

\section{Peroxidase assay}

The activity of peroxidase (POD) enzyme was assessed using guaiacol as substrate. $0.1 \mathrm{ml}$ of crude leaves extract $(0.1 \mathrm{ml})$ was combined with $2 \mathrm{ml}$ of guaiacol $(8 \mathrm{mM}$, in $100 \mathrm{mM}$ sodium phosphate buffer at $\mathrm{pH}$ of 6.4) and incubated for $30 \mathrm{~min}$ at $30{ }^{\circ} \mathrm{C}$. The increase in absorbance at $460 \mathrm{~nm}$ was measured after addition of $1 \mathrm{ml} \mathrm{H}_{2} \mathrm{O}_{2}(24 \mathrm{mM})$. The activity of POD, U460, estimated using the following equation:

$$
\mathrm{U} 460=0.01 \Delta \mathrm{OD} 460
$$


where U460 is the unit of enzyme at 460 wavelength, and $\triangle \mathrm{OD}$ is the change of optical density per mg of protein per min (Ippolito et al., 2000).

\section{Statistical analysis}

Analysis of variance test (ANOVA) using SPSS software was used to analyze the data and Duncan's multiple ranges test (Duncan, 1955) was used to compare the means.

\section{Results}

\section{Efficacy chemical inducers against powdery mildew pathogen}

The efficacy of the examined inducers and flusilazole was assessed against powdery mildew of cucumber on the basis of reduction in powdery mildew severity. The severity of powdery mildew significantly reduced as a result of foliar application of the applied chemical inducers. The data in (Table 1) and (Fig. 1) demonstrated that the flusilazole was the best treatment toward powdery mildew of cucumber followed by salicylic acid, potassium dihydrogen phosphate, magnesium sulfate, ferrous sulfate, oxalic acid and potassium monohydrogen phosphate, respectively, in both growing seasons.

\section{Impact of chemical inducers on some biochemical parameters of cucumber}

The results showed significant increase in the estimated biochemical parameters (chlorophyll content, peroxidase and polyphenoloxidase) in treated cucumber plants com-

\section{Table 1}

Effect of the tested treatments on the severity of powdery mildew of cucumber in the two growing seasons

\begin{tabular}{lcc}
\hline Treatments & Disease severity & \multicolumn{2}{c}{ Disease severity } \\
& $1^{\text {st }}$ season & $2^{\text {nd }}$ season \\
\hline Oxalic acid & $32.76 \pm 3.70 \mathrm{c}$ & $29.16 \pm 2.53 \mathrm{c}$ \\
Potassium dihydrogen phosphate & $17.42 \pm 1.08 \mathrm{f}$ & $16.17 \pm 1.66 \mathrm{f}$ \\
Ferrous sulfate & $28.23 \pm 3.10 \mathrm{~d}$ & $25.77 \pm 1.03 \mathrm{~d}$ \\
Salicylic acid & $13.47 \pm 1.20 \mathrm{~g}$ & $12.87 \pm 1.58 \mathrm{~g}$ \\
Sodium salicylate & $22.35 \pm 2.94 \mathrm{e}$ & $19.98 \pm 1.40 \mathrm{e}$ \\
Potassium monohydrogen phosphate & $37.84 \pm 2.85 \mathrm{~b}$ & $32.84 \pm 0.52 \mathrm{~b}$ \\
Magnesium sulfate & $27.52 \pm 2.14 \mathrm{~d}$ & $20.50 \pm 2.26 \mathrm{e}$ \\
Flusilazole & $8.14 \pm 0.88 \mathrm{~h}$ & $7.22 \pm 0.42 \mathrm{~h}$ \\
\hline Control & $89.49 \pm 1.62 \mathrm{a}$ & $87.89 \pm 2.25 \mathrm{a}$ \\
\hline
\end{tabular}

* Means in a column followed by the same letters are not significantly different using Duncan's multiple ranges test 
pare to untreated control (Figs 2, 3, 4). In addition, the highest enzymes activity and chlorophyll content in treated cucumber plants was registered for flusilazole followed by salicylic acid, potassium dihydrogen phosphate, magnesium sulphate, ferrous sulfate, oxalic acid and potassium monohydrogen phosphate, respectively.

\section{Effect of the examined elicitors on some growth and yield parameters of cucumber}

The assessed growth and yield characters (plant height, number of fruits/plant and yield/plant) of cucumber were considerably increased in treated cucumber plants compare to untreated control as presented in (Table 2). Moreover, the highest growth and yield characters (plant height, fruit number/plant and fruit yield) were for cucumber plants treated with flusilazole followed by salicylic acid, potassium dihydrogen phosphate, magnesium sulfate, ferrous sulfate, oxalic acid and potassium monohydrogen phosphate, respectively.

\section{Discussion}

Resistance elicitor's agents give an extra choice to control plant diseases with sustainable production. The examined mineral salts as chemical inducers showed high efficacy against powdery mildew of cucumber agrees with the findings of Reuveni et al. (1993). Also, phosphate salts showed potential effect against various diseases of cucumber (Mucharromah and Kuc, 1991) and this is makes it ideal biocompatible fungicides. In addition the outcomes of this study are in agreement with the findings of Krupinsky and

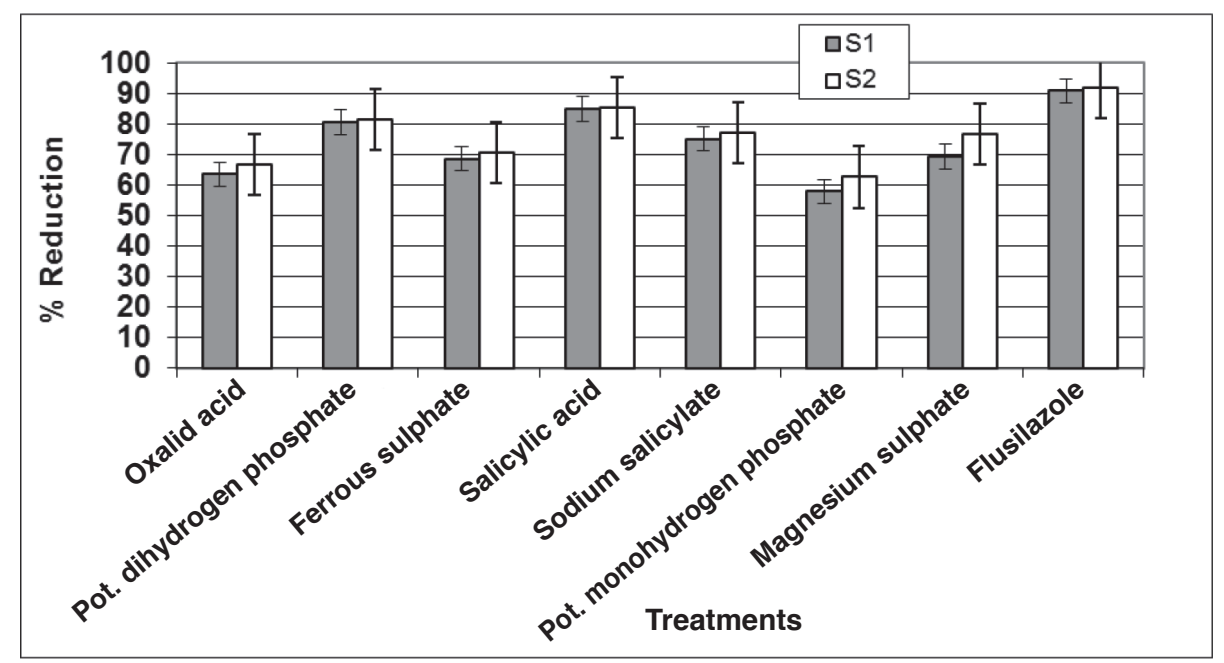

Fig. 1. Disease reduction of powdery mildew on cucumber under different treatments

in both growing seasons

$\mathrm{S} 1=$ Season $1, \mathrm{~S} 2=$ Season 2

* In each column the standard error of each mean was shown 
Tanaka (2000); Regmi et al. (2002) and Sharma et al. (2004), who reported that application of potassium salts minimized the diseases severity and raise crops yield.

The probable mode of action of the tested inducers against powdery mildew of cucumber may be due to its ionic components and its adverse effect on enzyme activities of the pathogen (Biggs et al., 1997; Miceli et al., 1999) or a contact osmotic mechanism

Table 2

Effect of the tested treatments on growth parameters in cucumber

\begin{tabular}{lcll}
\hline Treatments & $\begin{array}{c}\text { Plant height } \\
(\mathrm{m})\end{array}$ & Fruit number/plant & $\begin{array}{c}\text { Fruit yield } \\
\mathrm{kg} / \mathrm{plant}\end{array}$ \\
\hline Oxalic acid & $3.13 \pm 0.02 \mathrm{~d}$ & $24.00 \pm 1.0 \mathrm{f}$ & $3.30 \pm 0.05 \mathrm{e}$ \\
Potassium dihydrogen phosphate & $3.62 \pm 0.02 \mathrm{a}$ & $30.33 \pm 0.57 \mathrm{c}$ & $3.93 \pm 0.07 \mathrm{c}$ \\
Ferrous sulphate & $3.20 \pm 0.05 \mathrm{~d}$ & $25.67 \pm 0.57 \mathrm{e}$ & $3.30 \pm 0.05 \mathrm{e}$ \\
Salicylic acid & $3.65 \pm 0.05 \mathrm{a}$ & $33.00 \pm 1.0 \mathrm{~b}$ & $4.07 \pm 0.05 \mathrm{~b}$ \\
Sodium salicylate & $3.45 \pm 0.05 \mathrm{~b}$ & $28.33 \pm 0.57 \mathrm{~d}$ & $3.85 \pm 0.05 \mathrm{c}$ \\
Potassium monohydrogen phosphate & $2.98 \pm 0.07 \mathrm{e}$ & $23.33 \pm 0.75 \mathrm{f}$ & $3.25 \pm 0.05 \mathrm{e}$ \\
Magnesium sulfate & $3.33 \pm 0.11 \mathrm{c}$ & $28.33 \pm 0.57 \mathrm{~d}$ & $3.57 \pm 0.10 \mathrm{~d}$ \\
Flusilazole & $3.63 \pm 0.05 \mathrm{a}$ & $34.33 \pm 0.57 \mathrm{a}$ & $4.33 \pm 0.05 \mathrm{a}$ \\
Control & $2.28 \pm 0.07 \mathrm{f}$ & $20.33 \pm 0.57 \mathrm{~g}$ & $2.70 \pm 0.05 \mathrm{f}$ \\
\hline
\end{tabular}

* Means in a column followed by the same letters are not significantly different using Duncan's multiple ranges test

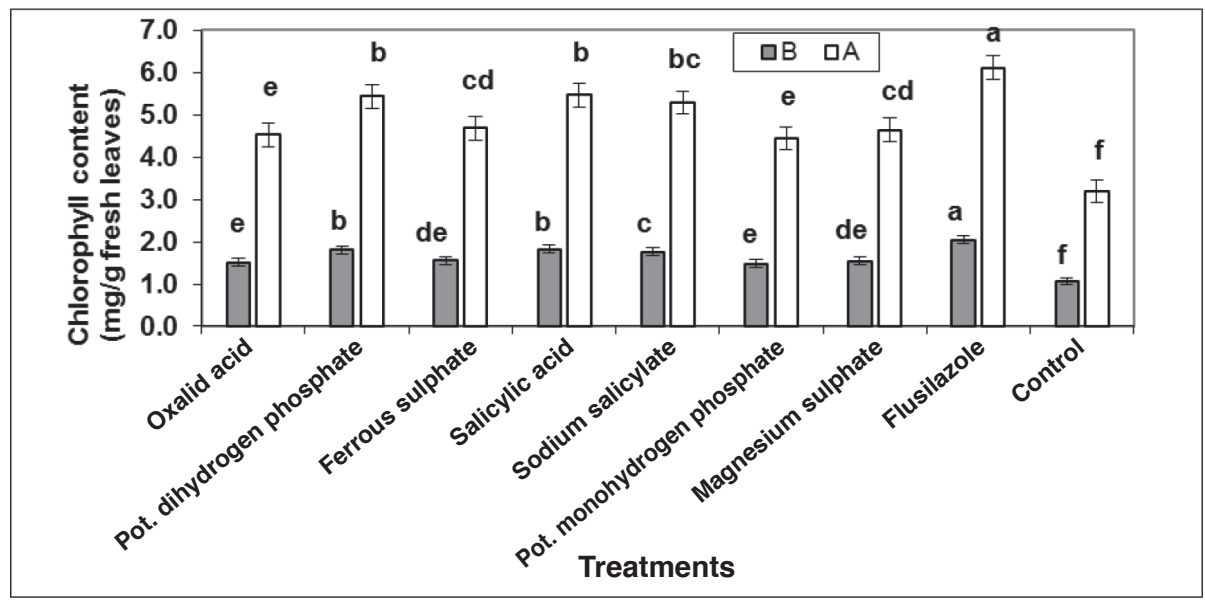

Fig. 2. Effect of the tested treatments on chlorophyll content ( $\mathrm{a}$ and $\mathrm{b}$ ) of in cucumber plants in the second season

* Means in a column followed by the same letters are not significantly different using Duncan's multiple ranges test

* A = Chlorophyll A, * B = Chlorophyl B

* Each treatment mean coming from three replicates

*In each column the standard error of each mean was shown 


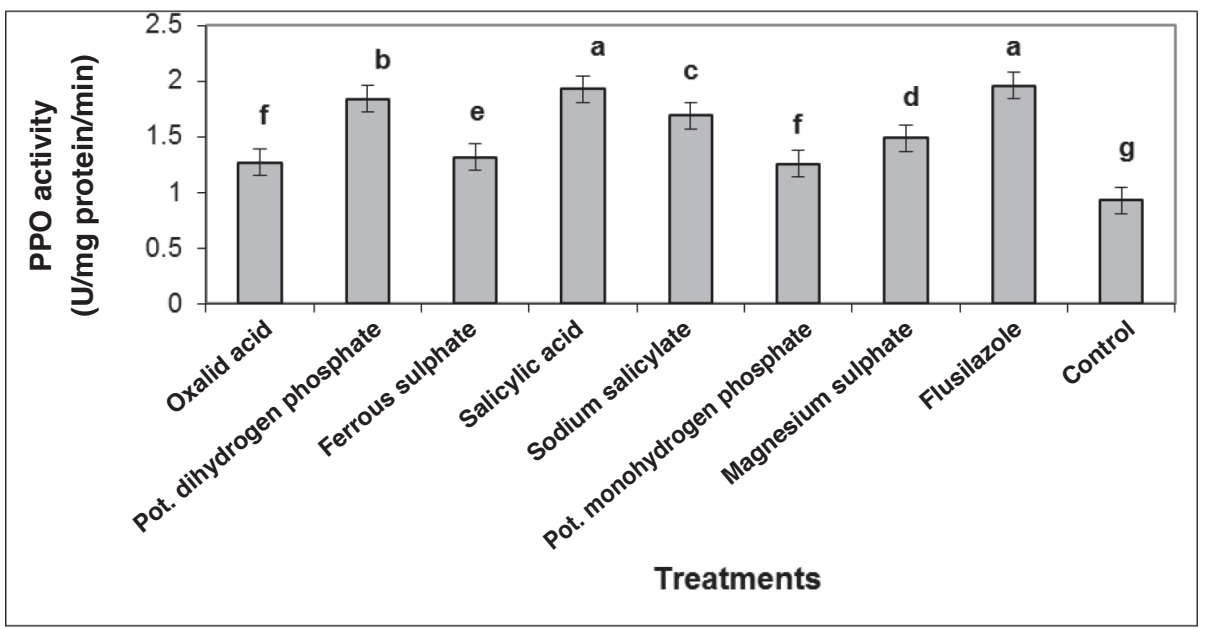

Fig. 3. Effect of the tested treatments on polyphenoloxadase activity in cucumber plants in the second season

* Means in a column followed by the same letters are not significantly different using Duncan's multiple ranges test

* Each treatment mean coming from three replicates

*In each column the standard error of each mean was shown

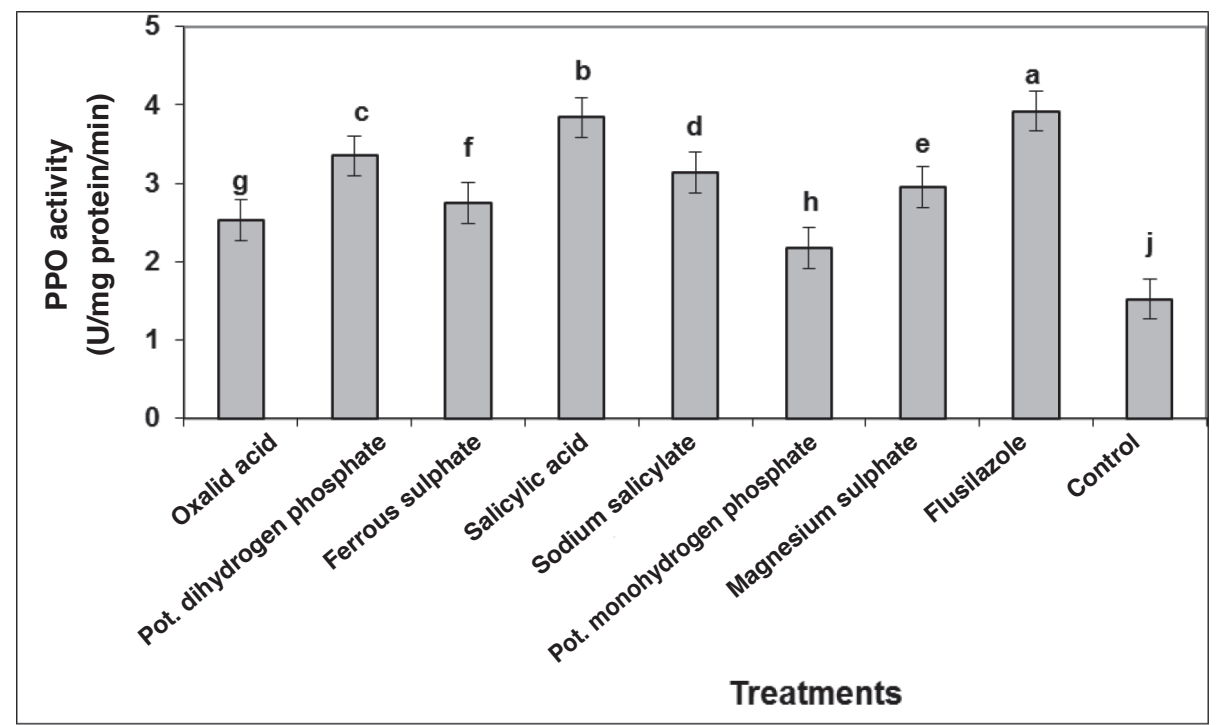

Fig. 4. Effect of the tested treatments on peroxidase activity in cucumber plants in the second season

* Means in a column followed by the same letters are not significantly different using Duncan's multiple ranges test

* Each treatment mean coming from three replicates

*In each column the standard error of each mean was shown 
at the phylloplane level (Mann et al., 2004). The mechanism of phosphate salts action against powdery mildew fungus in cucumbers not clearly identified till now. However, obviously both phosphate and potassium are included specifically or through the plant tissue in suppressing and inhibiting the powdery mildew fungus. A breakdown of hyphae and shrinkage of conidia and conidiophores treated with potassium bicarbonate has been watched (Homma and Arimoto, 1990). Furthermore, an inhibitory impact on conidial structure and germination of S. fuliginea was found (Homma et al., 1981) which may clarify the inhibitory characteristics of phosphate and potassium salts in our study.

Salicylic acid was the best chemical inducer toward powdery mildew of cucumber. Our results are in agreement with Mucharromah and Kuc (1991) who referred that, oxalate and phosphates induced systemic resistance against cucumber mosaic virus (CMV) by minimizing the number of CMV chlorotic lesions. The action of salicylic acid (SA) toward powdery mildew fungus might be because salicylic acid (SA) acts as the internal common resistance in plants and creates the expression of messenger RNA, that perhaps directs the synthesis of the pathogenesis-related (PR) proteins (Moffat, 1992). Also, Pieterse and Van Loon (1999) confirmed that, salicylic acid is an essential molecule included in both locally and systemically induced disease resistance responses. The efficacy of the tested magnesium and potassium salts as well as inorganic acids against $S$. fuliginea encouraged utilizing of these inducers for control powdery mildew of cucumber either alone or mixed with fungicides which is positively reflected on the reduction the applied amount of fungicides.

Potassium, ferrous and magnesium salts as well as oxalic and salicylic acids showed marked reduction of powdery mildew severity in cucumber which compatible with the findings of Abo El-Nasr et al. (2004) who found significant reduction in the infected lesions produced on cucumber and pepper plants by zucchini yellow mosaic virus (ZYMV) and potato virus Y (PVY), respectively, by the induction of SAR via several inducers such as salicylic acid, di-potassium phosphate, chelated iron, acid and oxalic acid, potassium sulfate, magnesium sulfate, ammonium sulfate, calcium super phosphate and calcium nitrates. The faster absorption rate of these salts, high mobility within plant tissues and low-cost nutrient value increase it chance for using to control plant pathogens. A double program consists of potassium and phosphates and application of traditional fungicides in time might suppress the evolution of fungicide-resistant strains of the pathogen under field conditions.

The examined fungicide (flusilazole) in this study showed resistance induction with remarkable increase in defense enzymes activity in treated cucumber plants as induced by examined chemical inducers. This is may be due to that the application of systemic fungicides such as flusilazole was found to induce extra amount of phenol as well as raised the action of all the defense enzymes as compared to contact fungicide (Haller et al., 2012).

The utilization of chemical inducers in this study for the improvement of host resistance is an option way to deal with plant pathogens control and is thought to be substantially more environmentally sound than conventional used fungicides. Despite the significant advancement in plant pathogens control by fungicides and plant breeding. Chemical fungicides were potentially hazardous in agriculture and induced adverse effects on the environment (El-Hendawy et al., 2010). Moreover, there is low confidence in genetically 
engineered crops by growers and consumers. So far the trend now to protect plants from diseases is the application of chemical inducers which will stimulate the natural defense mechanism of the infected plant. Due to the efficacy of the chemical inducers in this study, its cost effective, nutrient value and comparative safety, mineral salts and inorganic acids could be used or applied for control plant diseases under field conditions (Gottstein and $\mathrm{Ku}, 1989$; Reuveni et al., 1996).

The considerable increase in chlorophyll content of treated cucumber plants may be due to the minimization of reduced green leaf area affected by $S$. fuliginea fungus which serves to delay the loss of green leaf area due to disease (Paveley et al., 1997).

The outcomes in this study indicated considerable increase in defense enzymes activity compare to untreated control and this concur with discoveries of Stangarlin et al. (2011) who reported that the induction of resistance in plants includes the enhancement of defense enzymes activity in light of the treatment with elicitor agents against pathogens infection. The peroxidase (POX) is accountable for hydrogen atoms removal from hydroxyl cinnamic alcohols groups, whose radical polymerize to form the lignin. This polymer, beside with cellulose and other polysaccharides take a place in the cell wall of the superior plants, works as a physical barrier to prevent pathogen penetration. Polyphenol oxidizes (PPO) simulate the oxygen-dependent oxidation of $o$-dihydroxyphenols to $o$-quinones, which are more toxic to pathogens than previous. Direct toxicity of chemically synthetized quinones against pathogens has also been proposed (Mayer and Harel, 1979). Moreover, PPO is included in lignification of plant cells pending the pathogens infestation. These enzymes are likewise may take apart in the potentiating of vindication action in inducting resistance of plants to fungi, viruses and bacteria. Therefore the potential effect of the inducers against powdery mildew of cucumber may be due to the induction of cucumber resistance against this pathogen (Stangarlin et al., 2011). This induction by the simulation of defense enzymes which oxidize phenolic compounds to quinines (PPO) that known to be antimicrobial and toxic to the pathogen or through the synthesis of lignin (POX) that jointly with cellulose and different polysaccharides present in the cell wall of the plants, works as a physical obstruction to the pathogen entrance.

The marked increase in growth and yield parameters (plant height, fruit number/ plant and fruit yield) of cucumber after treating with the examined chemical inducers and fungicide may be due that the foliar application of different plant resistance inducers reduced of foliar diseases incidence which subsequently increased the growth and yield (Townsend and Heuberger, 1943). Since these chemical inducers increase reduce the loss of green area in plant leaves that affected by the pathogen which reflected positively on crop growth and yield (Paveley et al., 1997).

\section{Conclusions}

The examined inducers were possibly valuable for controlling powdery mildew of cucumber. These outcomes concluded that these elicitors are usable, safe and cost effective technique for protecting cucumber against foliar infections such as powdery mildew under greenhouse and might be under field conditions. 


\section{Literature}

Abo EI-Nasr, M. A., El- Dougdoug, K. A., El- Kattan, M. H. and Salem, E. A. (2004): Induction of salicylic acid in cucumber against ZYMV potyvirus by some nutrient chemicals. Egyp. J. Virol. 1, 301-312.

Arnon, D. I. (1949): Copper enzymes in isolated chloroplasts. Polyphenoloxidase in Beta vulgaris. Plant Physiol. 24, 1-15.

Biggs, A. R., El-Kholi, M. M., El-Neshawy, S. and Nickerson, R. (1997): Effects of calcium salts on growth, poly galacturonase activity, and infection of peach fruit by Monilinia fructicola. Plant Disease 81, 339-403.

Brent, K. J. and Holloman, D. W. (2007): Fungicide resistance in crop pathogens: How can it be managed? FRAC Monograph 1, second ed. In: Fungicide Resistance Action Committee Monograph 1. 2nd. ed. Crop Life International, Brussels. 56 p.

Duncan, D. B. (1955): Multiple ranges and multiple F. tests. Biometrics 11, 1-42.

El-Hendawy, S., Shaban, W. and Sakagami, J. (2010): Does treating faba bean seeds with chemical inducers simultaneously increase chocolate spot disease resistance and yield under field conditions. Turkish J. of Agriculture Forestry 34, 475-485.

El-Mougy, N. S. and Abdel-Kader, M. M. (2009): Salts application for suppressing potato early blight. J. of Plant Protect. Res. 49, 353-361.

El-Mougy, N. S., Abdel-Kader, M. M., Lashin, S. M. and Megahed, A. A. (2013): Fungicides alternatives as plant resistance inducers against foliar diseases incidence of some vegetables grown under plastic houses conditions. Inter. J. Engin. and Innovat. Technol. 3, 71-81.

Fungicide Resistance Action Committee (2011): FRAC Code List: Fungicides Sorted by Mode of Action. 12. Oct. 11. www.frac.info/frac/publication/anhang.

Galeazzi, M. A. M., Sgarbieri, V. C. and Constantinides, S. M. (1981): Isolation, purification and physicochemical characterization of polyphenoloxidases (PPO) from a dwarf variety of banana (Musa cavendishii L.). J. Food Sci. 46, 150-155.

Gottstein, H. D. and Ku, J. A. (1989): Induction of systemic resistance to anthracnose in cucumber by phosphates. Physiol. and Biochem. 79, 176-179.

Haller, H., Jadesha, G. and Prakasa, V. (2012): Impact of fungicides and botanicals on the induction of defense related enzymes in sugar beet plant against $C$. beticola. Green Farm. 3, 720-724.

Homma, Y. and Arimoto, Y. (1990): Mechanisms of plant disease control by potassium bicarbonate. Proc., 17th International Congress on Pesticide Chemistry, 2. 94 p.

Homma, Y., Arimoto, Y. and Misato, T. (1981): Studies on the control of plant diseases by sodium bicarbonate formulation. J. Pesticide Sci. 6, 201-209.

Ippolito, A., El Ghaouth, A., Wilson, C. L. and Wisniewski, M. (2000): Control of postharvest decay of apple fruit by Aureobasidium pullulans and induction of defense responses. Postharvest Biol. and Technol. 19, 265-272.

Krupinsky, J. M. and Tanaka, D. L. (2000): Leaf spot diseases on spring wheat influenced by the application of potassium chloride. In: A. J. Schlegel (ed.): Great Plains Soil Fertility Conference Proc., Vol. 8, Kansas State University, USA. pp. 171-176.

Mahdy, A. M. M., Abd El-Mageed, M. H., Hafez, M. A. and Ahmed, G. A. (2006): Using alternatives to control cucumber powdery mildew under green and commercial protected-house conditions. Fayoum J. Agric. Res. and Develop.20, 121-138.

Mann, R. L., Kettlewell, P. S. and Jenkinson, P. (2004): Effect of foliar-applied potassium chloride on septoria leaf blotch of winter wheat. Plant Pathol. 53, 653-659.

Marin, S., Guynot, M. E., Sanchis, V., Arbones, J. and Ramos, A. J. (2002): Aspergillus flavus, Aspergillus niger and Penicillium corylophillum spoilage prevention of bakery products by means of weak acid preservatives. J. Food Sci. 67, 2271-2277.

Mayer, A. M. and Harel, E. (1979): Polyphenol oxidases in plants. Phytochem. 18, 193-215.

McGrath, M. T. (2001): Fungicide resistance in cucurbit powdery mildew: experiences and challenges. Plant Dis. $85,236-245$. 
Miceli, A., Ippolito, A., Linsalata, V. and Nigro, F. (1999): Effect of preharvest calcium treatments on decay and biochemical changes of table grape during storage. Phytopathol. Mediter. 38, 47-53.

Moffat, A. S. (1992): Improving plant disease resistance. Science 257, 282-283.

Moran, R. and Porath, D. (1980): Chlorophyll determination in intact tissues using n,n-dimethylformamide. Plant Physiol. 65, 478-479.

Mucharromah, E. and Kuc, J. (1991): Oxalate and phosphates induce systemic resistance against diseases caused by fungi, bacteria and virus in cucumber. Crop Protect. 10, 230-265.

Pasche, J. S., Wharam, C. M. and Gudmestad, N. C. (2004): Shift in sensitivity of Alternaria solani in response to $\mathrm{Q}_{0}$ I fungicides. Plant Dis. 88, 181-187.

Paveley, N. D., Lockley, K. D., Sylvester-Bradley, R. and Thomas, J. (1997): Determination of fungicide spray decisions for wheat. Pesticide Sci. 49, 379-388.

Pieterse, C. M. and Van Loon, L. C. (1999): Salicylic acid independent plant defence pathways. Trends Plant Sci. 4, 52-58.

Ragab, M. M. M., Saber, M. M., El-Morsy, S. A. and Abd El-Aziz, A. R. M. (2009): Induction of systemic resistance against root rot of basil using some chemical inducers. Egypt. J. Phytopathol. 37, 59-70.

Regmi, A. P., Ladha, J. K., Pasuquin, E. M., Pathak, H., Hobbs, P. R., Shrestha, L. L., Gharti, D. B. and Duveiller, E. (2002): The role of potassium in sustaining yields in a long-term rice-wheat experiment in the Indo-Gangetic plains of Nepal. Biol. Fert. Soils 36, 240-247.

Reuveni, M., Agapov, V. and Reuveni, R. (1993): Induction of systemic resistance to powdery mildew and growth increase in cucumber by phosphates. Agric. Horticult. 9, 305-315.

Reuveni, M., Agapov, V. and Reuveni, R. (1996): Controlling powdery mildew caused by Sphaerotheca fuliginea in cucumber by foliar sprays of phosphate and potassium salts. Crop Protect. 15, 49-53.

Russell, P. E. (2004): Sensitivity baselines in fungicide resistance research and management. In: Fungicide Resistance Action Committee Monograph 3. Crop Life International, Brussels.

Sharma, S., Karki, C. B., Duveiller, E., Batsa, B. K. and Basnet, R. (2004): Effect of chemical fertilizers, farm manure and fungicides on leaf blight disease of wheat. Abstracts of the Fourth National Conference on Science and Technology. Royal Nepal Academy of Science and Technology, Kathmandu, Nepal, 23-26, 91-92.

Stangarlin, J. R., Kuhn, O. J., Toledo, M. V., Portz, R. L., Schwan-Estrada, K. R. F. and Pascholati, S. F. (2011): Plant defense against pathogens. Scientia Agraria Paranaensis, 10, 18-46.

Stromberge, A. and Brishammar, S. (1991): Induction of systemic resistance in potato (Solanum tuberosum L.) plants to late blight by local treatment with Phytophthora infestans, Phytophthora cryptogea or di-potassium phosphate. Potato Res. 34, 219-225.

Townsend, G. R. and Heuberger, J. W. (1943): Methods for estimating losses caused by diseases in fungicides experiments. Plant Dis. Report. 27, 340-343.

Vallad, G. E. and Goodman, R. M. (2004): Systemic acquired resistance and induced systemic resistance in conventional agriculture. Crop Sci. 44, 1920-1934.

Ziv, O. and Hagiladi, A. (1993): Controlling of powdery mildew in Euonymus with polymer coatings and bicarbonate solutions. Horticult. Sci. 28, 124-126.

Ziv, O. and Zitter, T. A. (1992): Effects of bicarbonates and film forming polymers on cucurbit foliar diseases. Plant Dis. 76, 513-517. 